\title{
Occurrence and Ecotoxicological Risk Assessment of Analgesics in Wastewater
}

\author{
Senar Aydin ${ }^{1}$, Mehmet Emin Aydin ${ }^{2}$, Havva Kiliç ${ }^{1}$, Arzu Ulvi ${ }^{1, *}$ \\ ${ }^{1}$ Environmental Engineering Department, Necmettin Erbakan University, Turkey \\ ${ }^{2}$ Civil Engineering Department, Necmettin Erbakan University, Turkey
}

Copyright $@ 2018$ by authors, all rights reserved. Authors agree that this article remains permanently open access under the terms of the Creative Commons Attribution License 4.0 International License

\begin{abstract}
In this study, concentrations of analgesics including acetaminophen (ACETAM), indomethacin (INDO), acetylsalicylic acid (ACETYL ACID), phenylbutazone (PHENYL) and codeine (CO) were determined in wastewaters and risk assessment for organisms in the receiving environment was carried out. The analytical method for determination of analgesics in wastewater was optimized. The detection of analgesics was carried out by HPLC-MS/MS. Limit of detection (LOD) values for studied compounds were determined between 0.017 and $0.197 \mu \mathrm{g} / \mathrm{L}$. Wastewater samples were taken from Konya Urban Wastewater Treatment Plant influent and effluent. ACETAM, CO, and INDO compounds were determined as $13000,150,80 \mathrm{ng} / \mathrm{L}$ in influent samples, respectively. ACETYL ACID and PHENYL were determined below limit of detection in influent samples. While INDO was determined about $84 \mathrm{ng} / \mathrm{L}$ in effluent samples, ACETAM and CO were determined up to $25 \mathrm{ng} / \mathrm{L}$. The analgesic compounds indicated insignificant risk for algae, Daphnia magna and fish in the receiving environment
\end{abstract}

Keywords Analgesics, Ecotoxicological Risk Assessment, Solid Phase Extraction, Wastewater

\section{Introduction}

Pharmaceutical compounds are used in medicine and veterinary, and agriculture. Pharmaceuticals are bioactive compounds that are resistant to biodegradation in the aquatic and terrestrial ecosystem. These compounds are the environmental pollutants and are classified according to their purpose e.g., antibiotics, analgesics, anti-inflammatory, psychiatric drugs [1]. Analgesics and non-steroidal anti-inflammatory drugs (NSAIDs) are among the most prescribed drugs. Therefore, a significant portion of pharmaceutical in wastewater is composed of anti-inflammatory and analgesic drugs. Analgesics are extensively used without prescription in many countries. Analgesics generally affect central nervous system and are used to prevent pain. Prolonged presence of xenobiotic such as analgesics in the aquatic environment increases the potential threat to people's endocrine system. Pharmaceuticals are generally released in natural waters via wastewater treatment plants (WWTP), hospitals, industrials, households and farming. Excretion is the major source of pharmaceutical pollution in water and soil. Pharmaceuticals reach to WWTPs as a result of direct use of people. Unused drugs also are thrown into the sewerage system by people. Pharmaceutical manufacturing factories are other sources of detected pharmaceuticals in environmental waters. After discharge of treated wastewater to sewage or receiving water, environmental water may contain pharmaceutical contaminant [2]. Some studies showed that pharmaceutical compounds are not exactly removed in conventional wastewater treatment plant. Removal rate of pharmaceuticals depends on physicochemical properties such as chemical structure, pKa value, log Kow value, and solubility. Conventional treatment processes is not effective to acidic drugs which have low $\mathrm{pKa}$ values such as acetylsalicylic acid (ACETYL ACID), indomethacin (INDO), phenylbutazone (PHENYL) $(2.5<\mathrm{pKa}<4.5)$ because these compounds are present soluble form in water at $\mathrm{pH}$ values above $\mathrm{pKa}$ values. The removals of these compounds also depend on seasonal variations. Advanced treatment methods are required for removal of pharmaceutical from wastewater [3]. However, some toxic intermediates and by-products are formed with advanced treatment methods. Toxicity tests must be applied whether by-products are toxic or not [4]. Analgesic compounds have been detected in surface waters, river water, treated and untreated drinking water, input and output of WWTP and sewage sludge at variable concentrations in the literature [5, 6, 7, and 8]. Gracia-Lor et al. [9] investigated acetaminophen (ACETAM) in surface water and wastewater. They determined ACETAM as $1968 \mathrm{ng} / \mathrm{L}$ in surface water and $201000 \mathrm{ng} / \mathrm{L}$ in wastewater. Lacey et al. [10] determined INDO in WWTP 
influent $(<0.263-<0.877 \mu \mathrm{g} / \mathrm{L})$ and effluent $(<0.238$ $<0.792 \mu \mathrm{g} / \mathrm{L}$ ). López-Serna et al. [11] investigated INDO, ACETAM, PHENYL and codeine (CO) compounds in drinking water, river water, WWTP effluent samples. INDO was detected between 16.27 and $37.75 \mathrm{ng} / \mathrm{L}$ in river water, $93.88 \mathrm{ng} / \mathrm{L}$ in effluent samples. ACETAM was detected $146.67 \mathrm{ng} / \mathrm{L}-307 \mathrm{ng} / \mathrm{L}$ in river water, $77.83 \mathrm{ng} / \mathrm{L}$ in effluent water. $\mathrm{CO}$ in river water, effluent samples was detected 45.85-109.68 ng/L, $350.12 \mathrm{ng} / \mathrm{L}$, respectively. INDO, ACETAM and CO compounds were not detected in drinking water. PHENYL was not detected in drinking water, river water and effluent water.

The aim of this study is analytical method optimization for determination of analgesics including ACETAM, INDO, ACETYL ACID, PHENY, and CO in wastewater; to determine concentrations of analgesics in WWTP inlet and outlet, to assess the ecotoxicological risk for the receiving environment.

\section{Materials and Methods}

\subsection{Standards and Reagents}

HPLC-grade methanol, acetonitrile, hydrochloric acid (37\%), formic acid (98\%) and $\mathrm{Na}_{2}$ EDTA (ethylenediaminetetraacetic acid disodium salt solution) were purchased from Merck. While ACETAM and INDO were purchased from Fluka, ACETYL ACID and PHENYL were purchased from Sigma. CO was supplied from Cerilliant. Glass fiber filter (GFF) $(1.2 \mu \mathrm{m})$ was obtained from Whatman, while nylon membrane filter was obtained from Sartorius. Oasis HLB (Hydrophilic Lipophilic) (60 mg, $3 \mathrm{~mL}$ ) and Oasis MCX (Mixed Polymeric Sorbent) $(150 \mathrm{mg}, 6 \mathrm{~mL})$ cartridges were purchased from Waters Corporation. High-purity nitrogen gas was obtained from the nitrogen generator (Peak Scientific).

\subsection{Sample Collection and Preparation}

Konya sewerage system is combined sewerage system. Wastewater and rainwater is collected in the same channel. The WWTP in Konya, Turkey serves approximately 1300000 people with an average wastewater flow of $170000 \mathrm{~m}^{3} /$ day. $24 \mathrm{~h}$ composite wastewater samples were taken from influent and effluent of Konya WWTP. Samples were kept at $4^{\circ} \mathrm{C}$ until analyzed. Wastewater samples filtered through $1.2 \mu \mathrm{m}$ GFF followed $0.45 \mu \mathrm{m}$ nylon membrane filters. $0.1 \quad \mathrm{M} \quad \mathrm{Na}_{2} \mathrm{EDTA}$ (final concentration, $0.1 \%$ ) was added to the samples as a chelating agent to reduce analgesic binding to cations [12].

Pre-concentration of samples was performed by solid phase extraction (SPE), using Oasis HLB and Oasis MCX cartridges. Oasis HLB and MCX cartridges were pre-conditioned with $\mathrm{MeOH}(2 \times 2.5 \mathrm{~mL})$ and HPLC-grade deionised water $(2 \times 2.5 \mathrm{~mL}, \mathrm{pH}$ adjusted 2.5 and 7.0$)$ at a flow rate of $2 \mathrm{~mL} / \mathrm{min}$. Aliquots of $200 \mathrm{~mL}$ of sample were loaded into the cartridge at a flow rate of $1 \mathrm{~mL} / \mathrm{min}$, rinsed with $2.5 \mathrm{~mL}$ of ultrapure water. Then, cartridges were eluted with $4 \times 2.5 \mathrm{~mL}$ of $\mathrm{MeOH}$ at $1 \mathrm{~mL} / \mathrm{min}$. Extracts were evaporated until almost dryness and re-constituted with $1 \mathrm{~mL}$ of methanol/water $(50 / 50, \mathrm{v} / \mathrm{v})$. The detection of analgesics was carried out by HPLC-MS/MS system.

\section{Results and Discussion}

\subsection{HPLC-MS/MS Analysis}

Agilent 1260 series HPLC system was used for analysis of analgesics. Separation was performed HPLC series 1260 equipped with Agilent Poroshell 120 EC-C18 $(3.0 \times 100 \mathrm{~mm}, 2.7 \mu \mathrm{m})$ analytical column. Analysis was carried out in positive (ESI + ) and negative (ESI-) ion mode by trying different mobile phases. Most suitable mobile phase was determined as $\mathrm{A}$ : water with $\% 0.1$ formic acid and $5 \mathrm{mM}$ ammonium formate, $\mathrm{B}$ : methanol for analgesics in positive ion mode, A: water with $10 \mathrm{mM}$ ammonium acetate, B: methanol for analgesics in negative ion mode. A linear gradient progressed with $90 \% \mathrm{~A}$ and $10 \% \mathrm{~B}$ for $1 \mathrm{~min}$, ramping to $30 \% \mathrm{~B}$ at $3 \mathrm{~min}, 70 \% \mathrm{~B}$ at 8 $\mathrm{min}, 95 \% \mathrm{~B}$ at $2 \mathrm{~min}$ and it was held for $2 \mathrm{~min}$. Optimal flow rate was determined as $0.3 \mathrm{~mL} / \mathrm{min}$, injection volume was determined as $2 \mu \mathrm{L}$.

LC-MS/MS analytical quality parameters limits of detection (LOD), limits of quantification (LOQ), linearity and $\mathrm{m} / \mathrm{z}$ values for are given in Table 1. LODs and LOQs were determined at a signal-to-noise ratio $(\mathrm{S} / \mathrm{N})$ of 3 and 10 , respectively.

Table 1. LOD, LOQ, linearity and $\mathrm{m} / \mathrm{z}$ values for analgesics obtained with HPLC-MS/MS systems

\begin{tabular}{|c|c|c|c|c|}
\hline Compounds & $\mathbf{m} / \mathbf{z}$ value & $\begin{array}{c}\text { LOD } \\
(\mathbf{n g} / \mathbf{L})\end{array}$ & $\begin{array}{c}\text { LOQ } \\
(\mathbf{n g} / \mathbf{L})\end{array}$ & $\mathbf{R}^{2}$ \\
\hline $\begin{array}{c}\text { ACETYL } \\
\text { ACID }\end{array}$ & $137[\mathrm{M}-\mathrm{H}]^{-}$ & 0.00015 & 0.000053 & 0.9944 \\
\hline ACETAM & $152,110[\mathrm{M}+\mathrm{H}]^{+}$ & 0.00098 & 0.0032 & 0.9944 \\
\hline CO & $300[\mathrm{M}+\mathrm{H}]^{+}$ & 0.0007 & 0.0023 & 0.9974 \\
\hline PHENYL & $309[\mathrm{M}+\mathrm{H}]^{+}$ & 0.00008 & 0.00028 & 0.9980 \\
\hline INDO & $358,231[\mathrm{M}+\mathrm{H}]^{+}$ & 0.0009 & 0.003 & 0.9974 \\
\hline
\end{tabular}

\subsection{Optimization of SPE}

The recovery experiments for the determination of efficiency of the SPE procedure were carried out. The optimum cartridge type, optimum volume of the solvent, optimum $\mathrm{pH}$ of the sample, and effects of the sample pre-treatment were determined. For that, $200 \mathrm{~mL}$ ultrapure water was spiked with $1000 \mathrm{ng} / \mathrm{L}$ of each analgesics and then $\mathrm{pH}$ of samples were adjusted to 2.5 and 7.0. SPE procedure was carried out using Oasis HLB and MCX cartridges. The recovery values of studied analgesics have been shown in Figure 1. 


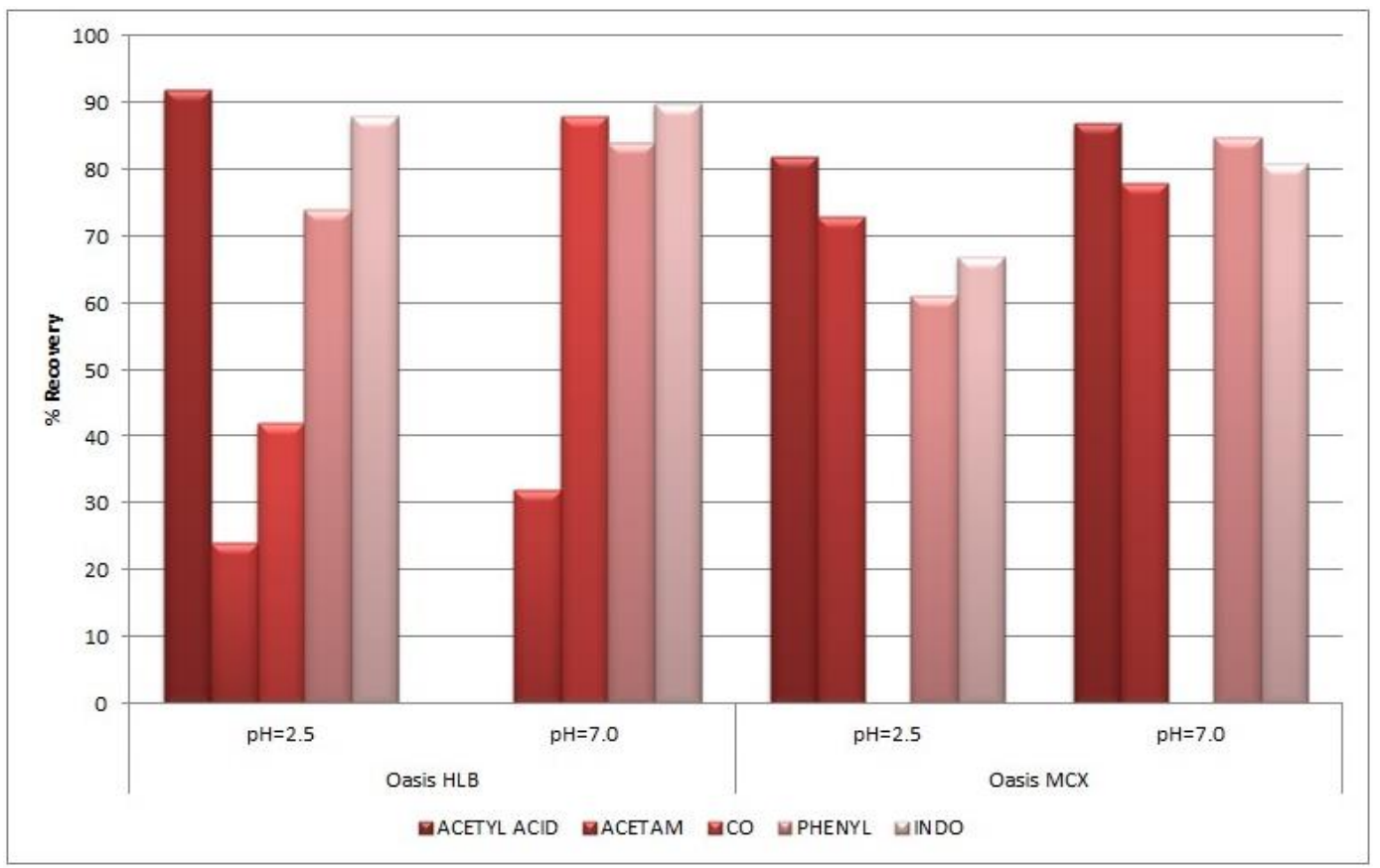

Figure 1. Recovery of analgesics from Oasis HLB and Oasis MCX cartridges at different $\mathrm{pH}$ values

The recovery values were determined between 24\% (ACETAM) and 92\% (ACETYL ACID) at pH 2.5 (SD $<3$ ), while the recovery values were determined $32 \%$ (ACETAM) and $90 \%$ (INDO) at $\mathrm{pH} 7.0$ value $(\mathrm{SD}<3)$ for Oasis HLB cartridge. ACETYL ACID and ACETAM compounds were extracted on HLB sorbent with the lowest recoveries at $\mathrm{pH}$ 7.0 value. Recoveries were obtained 61\% (PHENYL) and 82\% (ACETYL ACID) at $\mathrm{pH} 2.5$ value (SD $<4), 78 \%$ (ACETAM) and $87 \%$ (ACETYL ACID) at $\mathrm{pH} 7.0$ value (SD<2) for extraction by Oasis MCX cartridge.

Recovery value was not obtained for $\mathrm{CO}$ at $\mathrm{pH} 2.5$ and 7.0 by Oasis MCX cartridge. Therefore, Oasis MCX cartridge was used extraction of ACETYL ACID and ACETAM at pH 7.0 value. Extraction studies were continued using Oasis HLB cartridge for CO, PHENYL and INDO compounds at $\mathrm{pH} 7.0$ values.

The effect of sample volume on extraction was investigated. $100 \mathrm{~mL}$ and $200 \mathrm{~mL}$ ultrapure waters were fortified with $1000 \mathrm{ng} / \mathrm{L}$ of each analgesic compounds and $\mathrm{pH}$ of samples was adjusted to 7.0. SPE procedure was carried out. The recovery values are given in Figure 2.

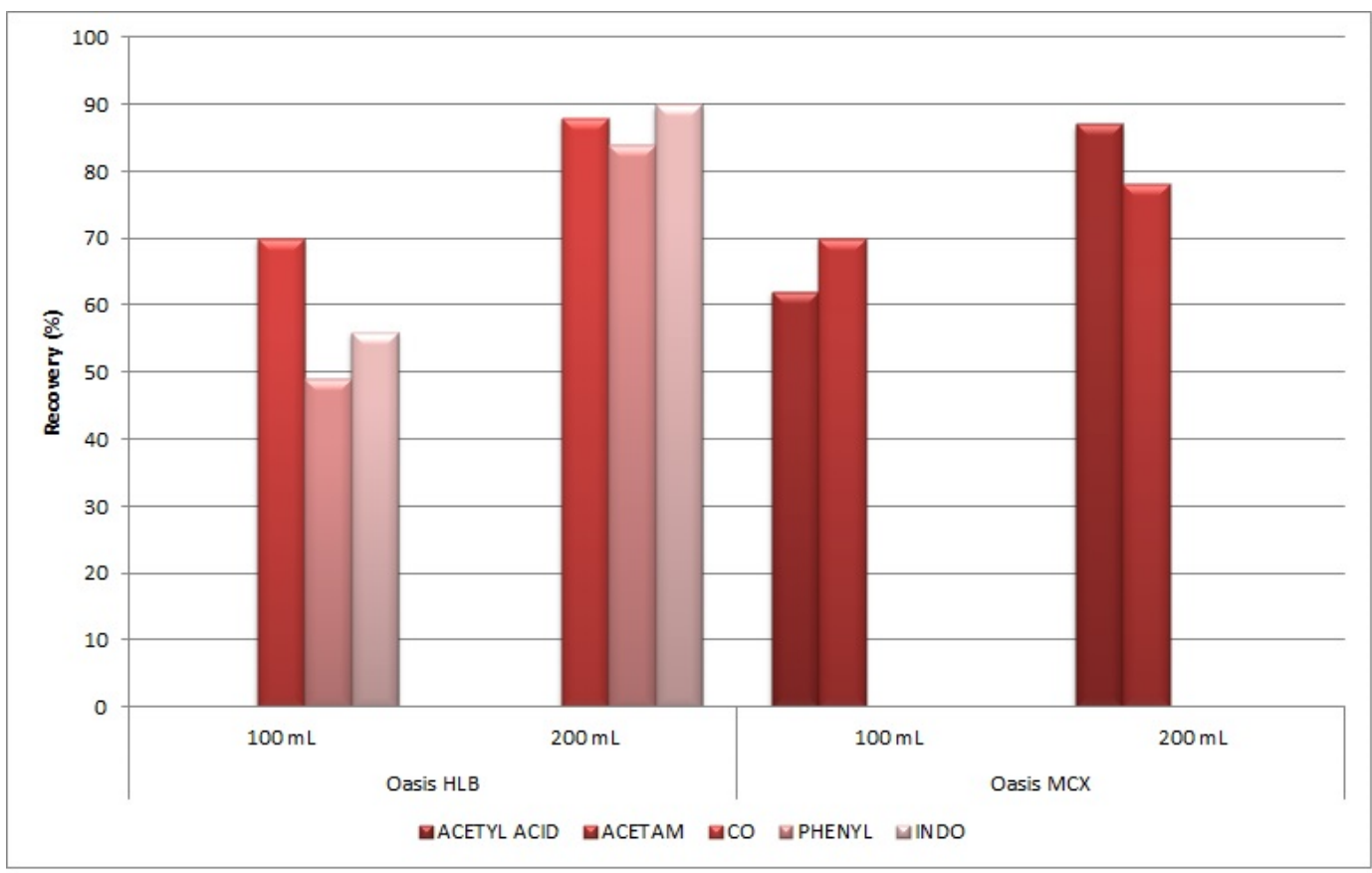

Figure 2. Recovery of analgesics for different sample volume 
Recoveries were obtained between 49\% (PHENYL) and 70\% (CO) for $100 \mathrm{~mL}$ sample volume (SD<6) and between $84 \%$ (PHENYL) and $90 \%$ (INDO) for $200 \mathrm{~mL}$ sample volume $(\mathrm{SD}<3)$. The obtained recovery values were between $62 \%$ (ACETYL ACID) and 70\% (ACETAM) for $100 \mathrm{~mL}$ sample volume (SD<3) and between $78 \%$ (ACETAM) and $87 \%$ (ACETYL ACID) for $200 \mathrm{~mL}$ sample volume ( $\mathrm{SD}<2$ ). $200 \mathrm{~mL}$ sample volume was chosen as optimum sample volume for extraction because of higher recoveries.

Effect of sample pre-treatment (filtration) on extraction was also examined. $1000 \mathrm{ng} / \mathrm{L}$ of each analgesic compound was spiked to $200 \mathrm{~mL}$ ultrapure water. $\mathrm{pH}$ of samples was adjusted to 7.0. Samples filtered through $1.2 \mu \mathrm{m}$ GFF followed by $0.45 \mu \mathrm{m}$ nylon membrane filters. Then SPE procedure applied. Recoveries have been shown in Figure 3 .

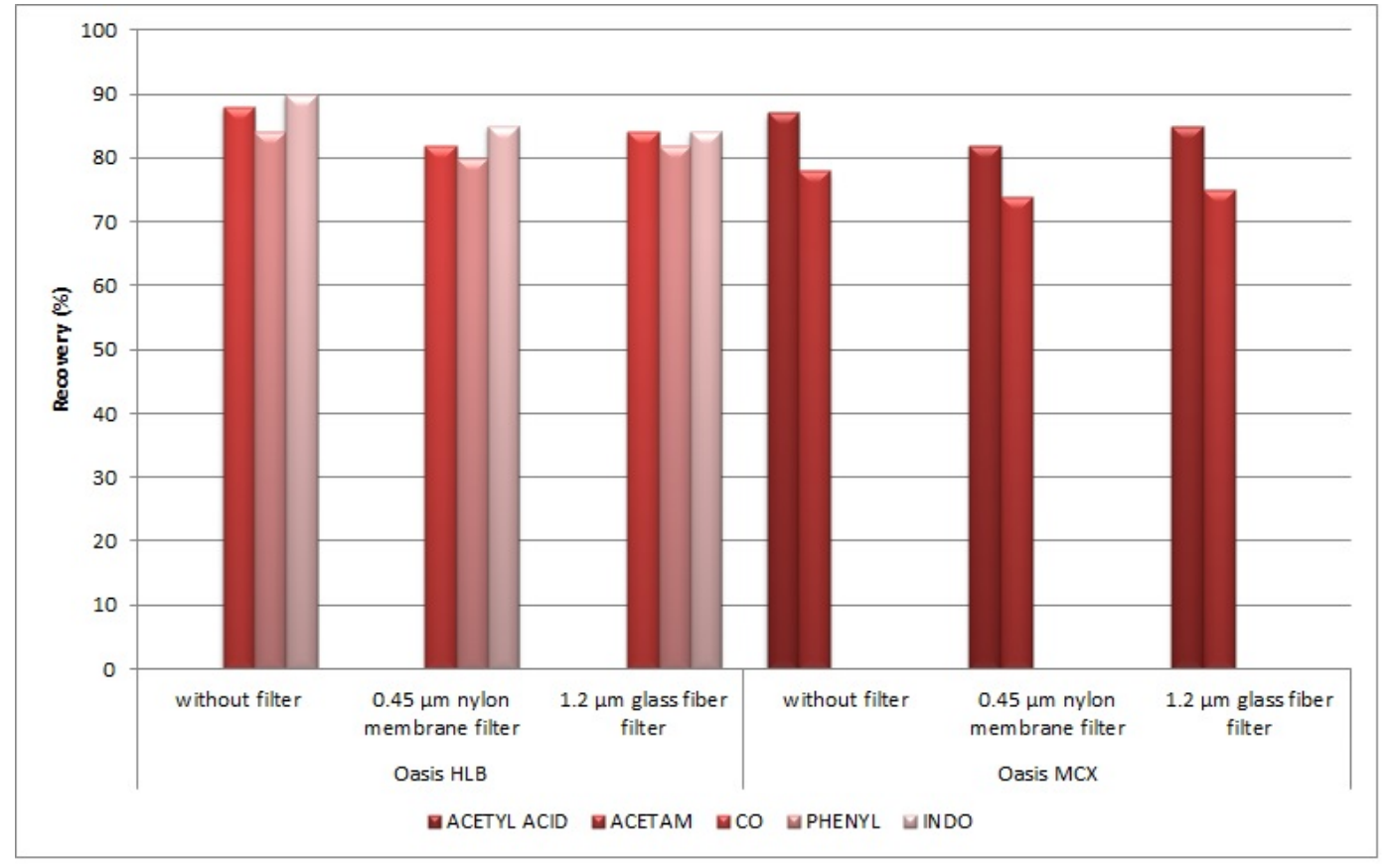

Figure 3. Effect of sample pre-treatment on the recovery of analgesics in water samples

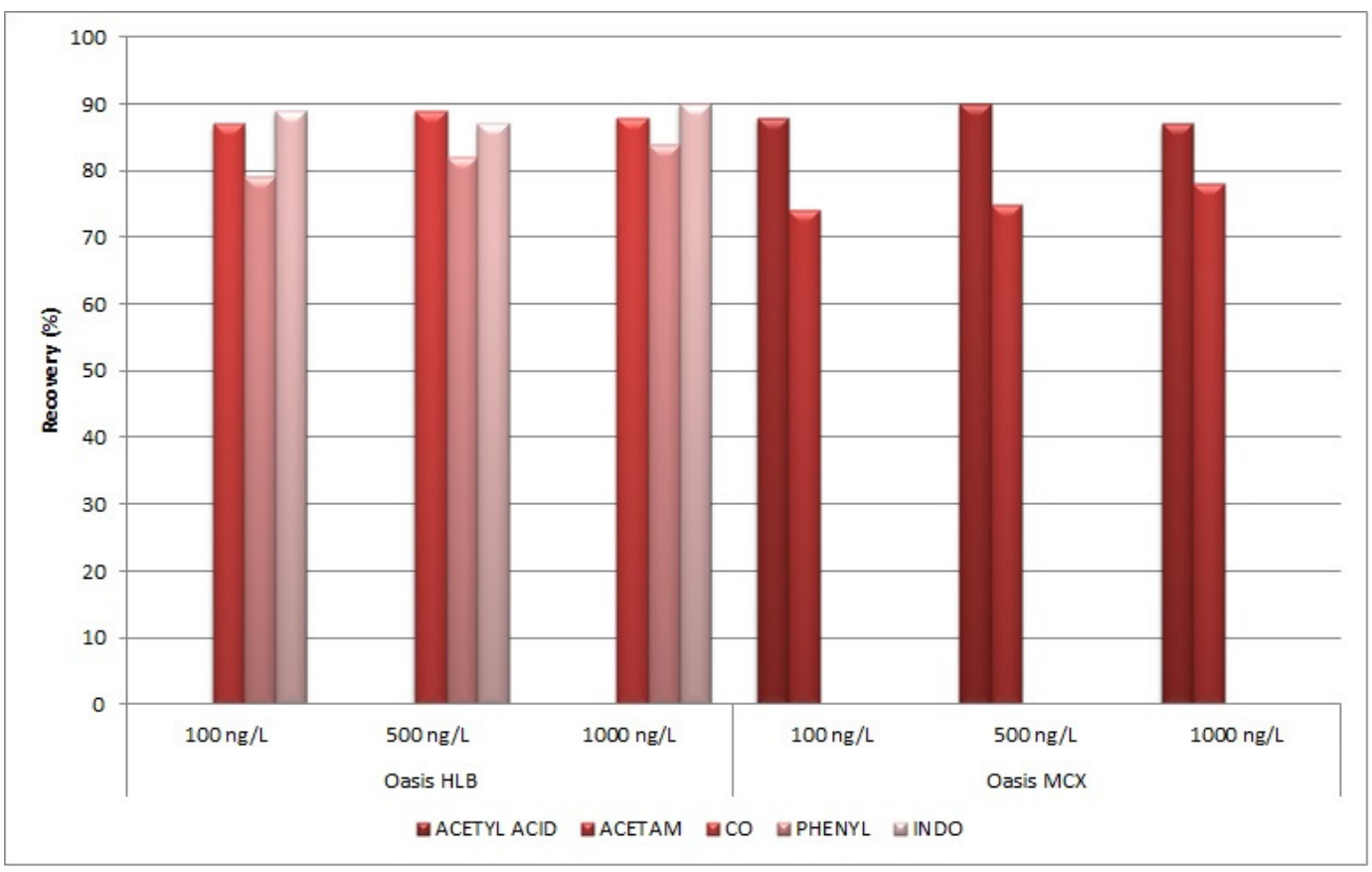

Figure 4. Recovery of analgesics for different analyte concentrations 


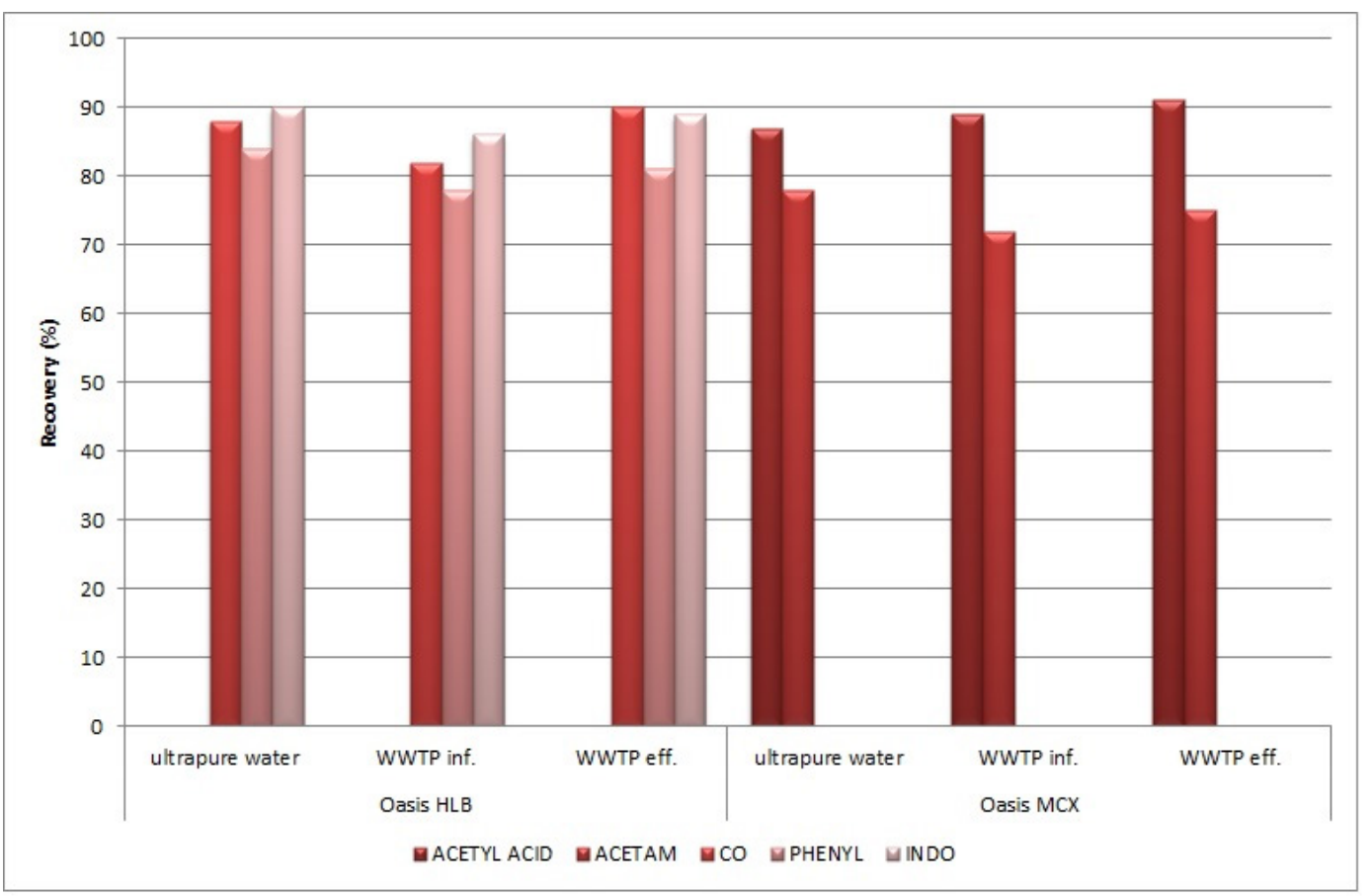

Figure 5. Effect of matrix on the recovery of analgesics in wastewater samples

The obtained recoveries were between 78\% (ACETAM) and 90\% (INDO) (SD<3) without filtration. Recoveries were changed between $74 \%$ (ACETAM) and $85 \%$ (INDO) $(\mathrm{SD}<6)$ filtrated nylon membrane filters with a $0.45 \mu \mathrm{m}$ pore diameter. Recovery values were between 75\% (ACETAM) and 85\% (ACETYL ACID) (SD<6) filtrated GFF with a 1.2 $\mu \mathrm{m}$ pore diameter. Negative effect of sample pretreatment was not determined on SPE. To determine effect of analyte concentration on extraction, $200 \mathrm{~mL}$ ultrapure water was fortified with $100,500,1000 \mathrm{ng} / \mathrm{L}$ of each analgesic compounds. After $\mathrm{pH}$ adjustment $(\mathrm{pH}=7.0)$, SPE procedure was applied. Recoveries were determined between $74 \%$ (ACETAM) and 89\% (INDO) (SD<6) for $100 \mathrm{ng} / \mathrm{L}$ spike concentration, between 75\% (ACETAM) and 90\% (ACETYL $\mathrm{ACID})(\mathrm{SD}<7)$ for $500 \mathrm{ng} / \mathrm{L}$ spike concentration, between 78\% (ACETAM) and 90\% (INDO) (SD $<3$ ) for $1000 \mathrm{ng} / \mathrm{L}$ spike concentration (Figure 4).

Negative effect of different pharmaceutical concentration was not determined on SPE. Finally matrix effect was also investigated. $200 \mathrm{~mL}$ composite wastewater samples were fortified with $500 \mathrm{ng} / \mathrm{L}$ of each analgesic compounds. Samples were filtered through $1.2 \mu \mathrm{m}$ GFF followed by $0.45 \mu \mathrm{m}$ nylon membrane filters. $0.1 \mathrm{M} \mathrm{Na}_{2} \mathrm{EDTA}(0.1 \%)$ was added all samples. Recoveries were changed between 78\% (ACETAM) and 90\% (INDO) (SD $<3$ ) for ultrapure water, between $72 \%$ (ACETAM) and 89\% (ACETYL ACID) (SD<6) for influent samples, between $75 \%$ (ACETAM) and $91 \%$ (ACETYL ACID) $(\mathrm{SD}<6)$ for effluent samples (Figure 5).

INDO was not detected in influent and effluent samples. CO, PHENYL, ACETYL ACID and ACETAM were detected as 126, 1768, 44, and $768 \mathrm{ng} / \mathrm{L}$ in influent samples, respectively. CO, PHENYL, ACETYL ACID and ACETAM were detected as $121,2860,88$, and $696 \mathrm{ng} / \mathrm{L}$ in effluent samples, respectively.

Obtained recovery values for determination of analgesics in waters in the literature are given in Table 2. 
Table 2. The recovery values of some analgesics in different matrix in literature (\%)

\begin{tabular}{|c|c|c|c|c|c|c|}
\hline Matrix & ACETAM & ACETYL ACID & $\mathrm{CO}$ & INDO & PHENYL & Ref. \\
\hline $\begin{array}{c}\text { Ground water } \\
\text { (Spiked } 100 \mathrm{ng} / \mathrm{L}) \\
(2.5 \mathrm{~mL} \text { sample volume }) \\
\end{array}$ & 40.27 & & 98.87 & & 78.05 & [11] \\
\hline $\begin{array}{c}\text { Ultrapure water } \\
(\text { Spiked } 100 \mu \mathrm{g} / \mathrm{L}) \\
(\text { Spiked } 1000 \mu \mathrm{g} / \mathrm{L}) \\
(100 \mathrm{~mL} \text { sample volume })\end{array}$ & $\begin{array}{l}30.7 \pm 1.2 \\
31.3 \pm 1.3\end{array}$ & $\begin{array}{c}9.7 \pm 4.5 \\
10.1 \pm 4.1\end{array}$ & & $\begin{array}{l}72.9 \pm 3.9 \\
72.7 \pm 4.2\end{array}$ & $\begin{array}{l}76.7 \pm 4.6 \\
77.5 \pm 4.3\end{array}$ & [13] \\
\hline $\begin{array}{c}\text { Ultrapure water } \\
(\text { Spiked } 100 \mu \mathrm{g} / \mathrm{L}) \\
(\text { Spiked } 1000 \mu \mathrm{g} / \mathrm{L}) \\
(100 \mathrm{~mL} \text { sample volume })\end{array}$ & $\begin{array}{l}31.6 \pm 2.4 \\
32.2 \pm 2.9\end{array}$ & $\begin{array}{l}12.7 \pm 3.6 \\
14.9 \pm 2.6\end{array}$ & & & & [14] \\
\hline $\begin{array}{c}\text { Sea water } \\
(\text { Spiked } 0.2 \mu \mathrm{g} / \mathrm{L}) \\
(\text { Spiked } 0.5 \mu \mathrm{g} / \mathrm{L}) \\
(\text { Spiked } 1 \mu \mathrm{g} / \mathrm{L}) \\
(500 \text { mL sample volume })\end{array}$ & $\begin{array}{l}11.2 \\
13.8 \\
14.7\end{array}$ & $\begin{array}{l}84.5 \\
81.7 \\
85.1\end{array}$ & & & & [15] \\
\hline $\begin{array}{c}\text { Hospital wastewater } \\
(\text { Spike } 1 \mu \mathrm{g} / \mathrm{L}) \\
(100 \mathrm{~mL} \text { sample volume) }\end{array}$ & & & 95.1 & 100 & & [16] \\
\hline $\begin{array}{c}\text { Wastewater } \\
\text { (Spiked } 200 \mathrm{ng} / \mathrm{L}) \\
\text { (100 mL sample volume) }\end{array}$ & & & $91-101$ & & & [17] \\
\hline $\begin{array}{c}\text { Treated wastewater } \\
\text { (irrigation water) } \\
\text { (Spiked } 100 \mathrm{ng} / \mathrm{L}) \\
\text { (1000 mL sample volume) }\end{array}$ & & & & $68 \pm 7$ & & [18] \\
\hline $\begin{array}{c}\text { Ultrapure water } \\
\text { (Spiked } 100 \mathrm{ng} / \mathrm{L}) \\
(2.5 \mathrm{~mL} \text { sample volume })\end{array}$ & & & & 55 & & [19] \\
\hline $\begin{array}{c}\text { Ground water } \\
\text { (Spiked } 100 \mathrm{ng} / \mathrm{L}) \\
(\text { Spiked } 500 \mathrm{ng} / \mathrm{L}) \\
\text { (100 mL sample volume) }\end{array}$ & $\begin{array}{l}35 \\
23\end{array}$ & $\begin{array}{c}100 \\
82\end{array}$ & & & & [20] \\
\hline $\begin{array}{c}\text { Ultrapure water } \\
\text { WWTP influent } \\
\text { WWTP effluent } \\
\text { (Spiked } 500 \mathrm{ng} / \mathrm{L}) \\
\text { (200 mL sample volume) }\end{array}$ & $\begin{array}{l}78 \pm 2 \\
72 \pm 5 \\
75 \pm 4\end{array}$ & $\begin{array}{l}87 \pm 2 \\
89 \pm 4 \\
91 \pm 6\end{array}$ & $\begin{array}{l}88 \pm 0 \\
82 \pm 6 \\
90 \pm 4\end{array}$ & $\begin{array}{l}90 \pm 2 \\
86 \pm 5 \\
89 \pm 6\end{array}$ & $\begin{array}{l}84 \pm 3 \\
78 \pm 5 \\
81 \pm 7\end{array}$ & $\begin{array}{l}\text { This } \\
\text { work }\end{array}$ \\
\hline
\end{tabular}

Shaaban and Górecki [13] developed a method for analysis of some pharmaceuticals including analgesics by ultra-high-pressure liquid chromatography-tandem mass spectrometry (UHPLC-MS/MS). SPE procedure was applied using Oasis HLB cartridge without $\mathrm{pH}$ adjustment. Recoveries were obtained between 9.7 $4.5 \%$ (ACETYL ACID) and $76.7 \pm 4.6 \%$ (PHENYL) for spiked $100 \mu \mathrm{g} / \mathrm{L}$ between $10.1 \pm 4.1 \%$ (ACETYL ACID) and $77.5 \pm 4.3 \%$ (PHENYL) for spiked $1000 \mu \mathrm{g} / \mathrm{L}$ to ultrapure water. Grujić et al. [20] determined analgesics in surface water, ground water and WWTP by HPLC-MS. SPE method was optimized at different sample $\mathrm{pH}$ and sample volume. The highest recovery was obtained at $100 \mathrm{~mL}$ sample volume and $\mathrm{pH}=3.0$. Recoveries were changed between $35 \%$ (ACETAM) and $100 \%$ (ACETYL ACID). Guerra et al. (2014) investigated analgesics by SPE-LC-MS/MS. ACETAM was determined as $36000-50000 \mathrm{ng} / \mathrm{L}$ concentration in influent, $16-62000 \mathrm{ng} / \mathrm{L}$ in effluent. CO was determined as $77-5700 \mathrm{ng} / \mathrm{L}$ in influent, 80-3300 ng/L in effluent. 


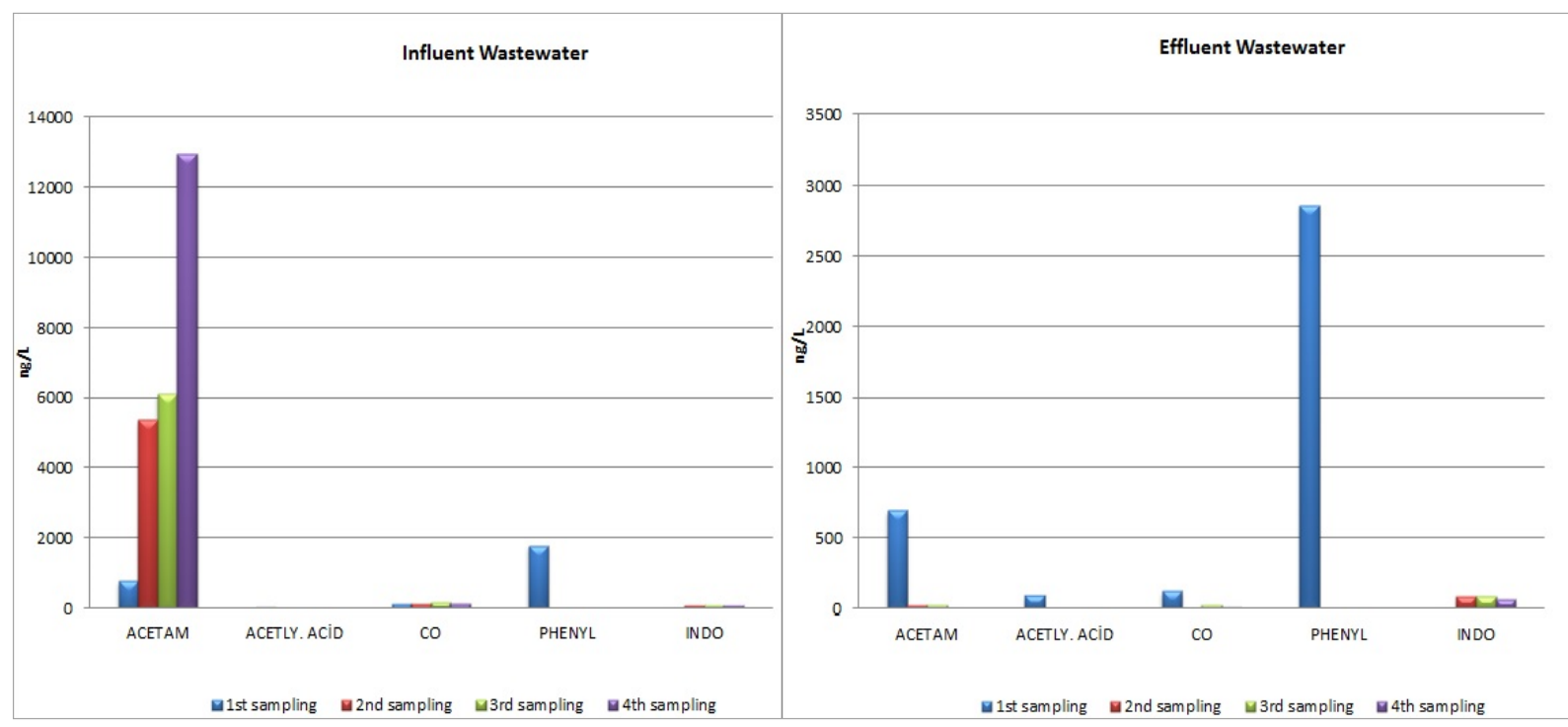

Figure 6. Concentration of investigated analgesics in influent and effluent sample at Konya WWTP

Table 3. Concentration of analgesic compounds in influent and effluent at the WWTP in literature

\begin{tabular}{|c|c|c|c|c|}
\hline Compounds & WWTP influent (ng/L) & WWTP effluent (ng/L) & Country & Ref. \\
\hline \multirow{7}{*}{ ACETAM } & & 77.83 & Spain & [21] \\
\hline & $36000-50000$ & $16-62000$ & Canada & {$[5]$} \\
\hline & $5530-292000$ & $<\mathrm{dl}-0.001$ & France & [22] \\
\hline & 70 & 60 & South Korea & [23] \\
\hline & & $140-1480$ & Germany & [24] \\
\hline & 31.9 & 0.01 & South Korea & {$[25]$} \\
\hline & $768-12956$ & $<$ dl-696 & Turkey & This work \\
\hline \multirow{3}{*}{ ACETYL ACID } & $<\mathrm{dl}$ & $28-37$ & Romania & {$[26]$} \\
\hline & $<\mathrm{dl}$ & $50-1510$ & Germany & {$[27]$} \\
\hline & $<\mathrm{dl}-44$ & $<\mathbf{d l - 8 8}$ & Turkey & This work \\
\hline \multirow{6}{*}{$\mathrm{CO}$} & & 350120 & Spain & {$[21]$} \\
\hline & $77-5700$ & $80-3300$ & Canada & {$[5]$} \\
\hline & 160 & 82 & Indian & {$[28]$} \\
\hline & 79 & 25 & Indian & [28] \\
\hline & 123 & 24 & Slovakia & {$[29]$} \\
\hline & $124-166$ & $<$ dl-121 & Turkey & This work \\
\hline \multirow{2}{*}{ PHENYL } & & $<\mathrm{dl}$ & Spain & [21] \\
\hline & $<$ dl-1768 & $<$ dl-2860 & Turkey & This work \\
\hline \multirow{5}{*}{ INDO } & $<\mathrm{dl}-877$ & $<\mathrm{dl}-792$ & Ireland & [10] \\
\hline & & 93.88 & Spain & {$[21]$} \\
\hline & $<\mathrm{dl}-297$ & $<\mathrm{dl}$ & Greece & {$[30]$} \\
\hline & 359.1 & $<\mathrm{dl}$ & Singapore & [31] \\
\hline & $<$ dl-78 & $<$ dl-84 & Turkey & This work \\
\hline
\end{tabular}




\subsection{Analgesic Concentrations in Wastewater}

Analgesics were determined in influent and effluent samples in four sampling periods including July, August, September and October. Figure 6 show detected analgesic concentrations in influent and effluent at Konya WWTP.

The highest concentration was determined ACETAM about $13000 \mathrm{ng} / \mathrm{L}$ in influent. $\mathrm{CO}$ and INDO compounds were detected about 150 and $80 \mathrm{ng} / \mathrm{L}$ respectively. ACETYL ACID and PHENYL compounds were determined below limit of detection in influent

INDO was detected higher concentrations about 84 $\mathrm{ng} / \mathrm{L}$. ACETAM and CO compounds were determined up to $25 \mathrm{ng} / \mathrm{L}$ in effluent sample. ACETYL ACID was detected below limit of detection. Concentrations of ACETAM, ACETYL ACID, CO, and PHENYL compounds were determined lower in effluent than influent.

INDO was detected at similar concentration in influent and effluent samples.

Concentration of analgesic in influent and effluent samples in different study and this study is presented in Table 3. According to Turkey, ACETAM in Canada and France, CO in Canada, PHENYL in Greece have been identified at high concentration.

\subsection{Ecotoxicological Risk Assessment}

Ecotoxicological effects of investigated compounds must be revealed. Pharmaceutical compounds have several potential risks on organism. There are some literature works on ecotoxicological risk assessment of analgesics. Gómez-Oliván et al. [32] determined DNA damage in Daphnia magna by ACETYL ACID. They concluded that ACETYL ACID had sublethal effect on Daphnia magna.

The hazard quotient (HQ) value was calculated for all compounds according to EU guidelines. The HQ value was calculated as quotient between the measured environmental concentration (MEC) and the Predicted No Effect Concentration (PNEC).

The individual concentration quantified for each analgesic compounds in the wastewater samples was taken as MEC. PNEC values were derived from the available aquatic toxicity data using three different species (algae, crustaceans and fish) from different tropic levels. PNEC values are given Table 4. PNEC value for PHENYL was not defined in the literature. If HQ values are below 0.1 , there is not adverse effect which means insignificant risk HQ values between 0.1 and 1 means the risk is low, HQ values between 1 and 10 means the risk is moderate and HQ values above 10 than the risk is high $[33,34]$.

Table 4. PNEC values for analgesic $(\mu \mathrm{g} / \mathrm{L})$

\begin{tabular}{|c|c|c|c|c|}
\hline Compounds & Fish & Daphnia magna & Algae & Ref. \\
\hline ACETAM & 378 & 9.2 & 134 & {$[35]$} \\
\hline $\begin{array}{c}\text { ACETYL } \\
\text { ACID }\end{array}$ & 150 & 88 & 106.7 & {$[36]$} \\
\hline CO & 238 & 16 & 23 & {$[37]$} \\
\hline PHENYL & - & - & - & - \\
\hline INDO & 3.9 & 26 & 18 & {$[37]$} \\
\hline
\end{tabular}

The HQ values of investigated analgesics were given in Table 5. All analgesic compounds showed insignificant risk (MEC/PNEC $<0.1)$ on algae, Daphnia magna and fish. High risk or medium risk was not determined for three different species.

There are very few studies on the ecotoxicological risk assessment of pharmaceuticals in the literature. Mendoza et al., [34] reported that the ACETAM compound has a high risk of Daphnia magna and INDO compounds have insignificant risk Algae. Gros et al. [38] have determined that ACETAM and CO compounds show insignificant risk to algae and fish.

Table 5. HQ values of investigated analgesics

\begin{tabular}{|c|c|c|c|c|c|c|c|c|c|c|c|c|}
\hline \multirow{3}{*}{ Compounds } & \multicolumn{12}{|c|}{ HQ (MEC/PNEC) } \\
\hline & \multicolumn{3}{|c|}{$1^{\text {st }}$ sampling } & \multicolumn{3}{|c|}{$2^{\text {nd }}$ sampling } & \multicolumn{3}{|c|}{$3^{\text {rd }}$ sampling } & \multicolumn{3}{|c|}{$4^{\text {th }}$ sampling } \\
\hline & Fish & $\begin{array}{c}\text { Daphnia } \\
\text { magna }\end{array}$ & Algae & Fish & $\begin{array}{c}\text { Daphnia } \\
\text { magna }\end{array}$ & Algae & Fish & $\begin{array}{c}\text { Daphnia } \\
\text { magna }\end{array}$ & Algae & Fish & $\begin{array}{c}\text { Daphnia } \\
\text { magna }\end{array}$ & Algae \\
\hline ACETAM & 0.0018 & 0.0757 & 0.0052 & 0.0001 & 0.0023 & 0.0002 & 0.0001 & 0.0026 & 0.0002 & ND & ND & ND \\
\hline $\begin{array}{c}\text { ACETYL } \\
\text { ACID }\end{array}$ & 0.0006 & 0.0010 & 0.0008 & ND & ND & ND & ND & ND & ND & ND & ND & ND \\
\hline $\mathrm{CO}$ & 0.0005 & 0.0076 & 0.0053 & ND & ND & ND & 0.0001 & 0.0015 & 0.0010 & 0 & 0.0007 & 0.0005 \\
\hline PHENYL & ND & ND & ND & ND & ND & ND & ND & ND & ND & ND & ND & ND \\
\hline INDO & ND & ND & 0.0000 & 0.0216 & 0.0032 & 0.0047 & 0.0214 & 0.0032 & 0.0046 & 0.0169 & 0.0025 & 0.0037 \\
\hline
\end{tabular}

ND: Not determined 


\section{Conclusions}

A method has been developed for analysis of five analgesic using SPE-LC-MS/MS. Oasis HLB and Oasis MCX cartridges were used for extraction of analgesic compounds. Optimum $\mathrm{pH}$ of sample was determined as 7.0 , sample volume was selected as $200 \mathrm{~mL}$ for extraction of analgesics. Adverse effects of different pharmaceuticals concentrations, filtering and matrix on SPE were not determined. Then optimized method was applied to real wastewater. Analgesics were detected up to $13000 \mathrm{ng} / \mathrm{L}$ concentrations in influent; the highest analgesic concentration was obtained $84 \mathrm{ng} / \mathrm{L}$ in wastewater treatment plant effluent. Analgesic concentrations were determined lower in effluent samples than influent samples for ACETAM, ACETYL ACID, CO, PHENYL compounds. INDO has detected similar concentration in influent and effluent samples. The all compounds indicated insignificant risk for algae, Daphnia magna and fish.

Pharmaceutical compounds are among the major environmental pollutants because they are designed to directly affect living things. Because conventional wastewater treatment plants are inadequate for pharmaceutical treatment, the main sources of pharmaceuticals in environment are wastewater discharges. Analytical methods are needed for determining the pharmaceutical concentrations in complex matrices.

This study provided both analytical method and information on the concentration of analgesics among the most consumed pharmaceuticals in wastewater. Also, more ecotoxicological studies are needed to fully assess the risks of pharmaceuticals.

\section{Acknowledgements}

This study was supported by TUBA-GEBIP Project and Scientific Research Projects Coordination Unit of Necmettin Erbakan University (Project no:131219004).

\section{REFERENCES}

[1] K. Kümmerer, Pharmaceuticals in the Environment; Sources, Fate, Effects and Risks, Freiburg, Germany, 2008.

[2] A. Ziylan, N. H. Ince, Review, The occurrence and fate of anti-inflammatory and analgesic pharmaceuticals in sewage and fresh water: Treatability by conventional and non-conventional processes, Journal of Hazardous Materials, 187, 24-36, 2011.

[3] J. Radjenovic, M. Petrovic, D. Barcelo, Fate and distribution of pharmaceuticals in wastewater and sewage sludge of the conventional activated sludge (CAS) and advanced membrane bioreactor (MBR) treatment, Water Research, 43, 831- 841, 2009.

[4] K. Li, A. Yediler, M. Yang, S. Schulte-Hostede, M. H.
Wong, Ozonation of oxytetracycline and toxicological assessment of its oxidation by-products, Chemosphere, 72, 473-478, 2008.

[5] P. Guerra, M. Kim, A. Shah, M. Alaee, S. A. Smyth, Occurrence and fate of antibiotic, analgesic/anti-inflammatory, and antifungal compounds in five wastewater treatment processes, Science of the Total Environment, 473-474, 235-243, 2014.

[6] R. Rosal, A. Rodríguez, J. A. Perdigón-Melón, A. Petre, E. García-Calvo, M. J. Gómez, A. Agüera, A. R. Fernández-Alba, Occurrence of emerging pollutants in urban wastewater and their removal through biological treatment followed by ozonation, Water Research, 44, 578-588, 2010.

[7] Y. Valcárcel, S. González Alonso, J. L. Rodríguez-Gil, A. Gil, M. Catalá, Detection of pharmaceutically active compounds in the rivers and tap water of the Madrid Region (Spain) and potential ecotoxicological risk, Chemosphere, 84, 1336-1348, 2011.

[8] C. Wang, H. Shi, C. D. Adams, S. Gamagedara, I. Stayton, T. Timmons, Y. Ma, Investigation of pharmaceuticals in Missouri natural and drinking water using high performance liquid chromatography-tandem mass spectrometry, Water Research, 45, 1818-1828, 2011.

[9] E. Gracia-Lor, J. V. Sancho, F. Hernández, Multi-class determination of around 50 pharmaceuticals, including 26 antibiotics, in environmental and wastewater samples by ultra-high performance liquid chromatography-tandem mass spectrometry, Journal of Chromatography A, $1218,2264-2275,2011$

[10] C. Lacey, G. McMahon, J. Bones, L. Barron, A. Morrissey, J.M. Tobin, An LC-MS method for the determination of pharmaceutical compounds in wastewater treatment plant influent and effluent samples, Talanta, 75, 1089-1097, 2008.

[11] R. López-Serna, A. Jurado, E. Vázquez-Suñé, J. Carrera, M. Petrović, D. Barceló, Occurrence of 95 pharmaceuticals and transformation products in urban groundwater underlying the metropolis of Barcelona, Spain, Environmental Pollution, 174, 305-315, 2013.

[12] R. López-Serna, M. Petrović, D. Barceló, Development of a fast instrumental method for the analysis of pharmaceuticals in environmental and wastewaters based on ultrahigh performance liquid chromatography (UHPLC)-tandem mass spectrometry (MS/MS), Chemosphere, 85, 1390-1399, 2011.

[13] H. Shaaban, T. Górecki, High temperature-high efficiency liquid chromatography using sub- $2 \mu \mathrm{m}$ coupled columns for the analysis of selected non-steroidal anti-inflammatory drugs and veterinary antibiotics in environmental samples, Analytica Chimica Acta, 702, 136-143, 2011.

[14] H. Shaaban, T. Górecki, Fast ultra-high performance liquid chromatographic method for the simultaneous determination of 25 emerging contaminants in surface water and wastewater samples using superficially porous sub-3 $\mu \mathrm{m}$ particles as an alternative to fully porous sub-2 $\mu \mathrm{m}$ particles, Talanta, 100, 80-89, 2012.

[15] P. Paíga, A. Lolić, F. Hellebuyck, L.H.M.H.M. Santos, M. Correia, C. Delerue-Matos, Development of a SPEUHPLC-MS/MS methodology for the determination of 
non-steroidal anti-inflammatory and analgesic pharmaceuticals in seawater, Journal of Pharmaceutical and Biomedical Analysis, 61-70, 2015.

[16] M. J. Gómez, M. Petrović, A. R. Fernández-Alba, D. Barceló, Determination of pharmaceuticals of various therapeutic classes by solid-phase extraction and liquid chromatography-tandem mass spectrometry analysis in hospital effluent wastewaters, Journal of Chromatography A, 1114, 224-233, 2006.

[17] E. Vuori, M. Happonen, M. Gergov, T. Nenonen, A. Järvinen, R. A. Ketola, R. Vahala, Wastewater analysis reveals regional variability in exposure to abused drugs and opioids in Finland, Science of the Total Environment, 487, 688-695, 2014.

[18] F. Chen, G. G. Ying, L-X. Kong, L. Wang, J. L. Zhao, L. J. Zhou, L. J. Zhang, Distribution and accumulation of endocrine-disrupting chemicals and pharmaceuticals in wastewater irrigated soils in Hebei, China, Environmental Pollution, 159, 1490- 1498, 2011.

[19] R. López-Serna, S. Pérez, A. Ginebreda, M. Petrović, D. Barceló, Fully automated determination of 74 pharmaceuticals in environmental and waste waters by online solid phase extraction-liquid

chromatography-electrospray-tandem mass spectrometry, Talanta, 83, 410-424, 2010.

[20] S. Grujić, T. Vasiljević, M. Laušević, Determination of multiple pharmaceutical classes in surface and ground waters by liquid chromatography-ion trap-tandem mass spectrometry, Journal of Chromatography A, 1216, 49895000, 2009.

[21] R. López-Serna, S. Pérez, A. Ginebreda, Petrović, M. D. Barceló, Fully automated determination of 74 pharmaceuticals in environmental and waste waters by online solid phase extraction-liquid chromatography-electrospray-tandem mass spectrometry, Talanta, 83, 410-424, 2010.

[22] D. Sirbu, D. Curseu, M. Popa, A. Achimas-Cadariu, Z. Moldovan, Environmental risks of pharmaceuticals and personal care products in water, in: Tenth, International Water Technology Conference, Alexandria, Egypt, 2006.

[23] K. P. Henschel, A. Wenzel, M. Diedrich, , A. Flieder, Environmental Hazard Assessment of Pharmaceuticals, Regulatory Toxicology and Pharmacology, 3, 220-225, 1997.

[24] Y. Zhang, S. U. Geißen, C. Gal, Carbamazepine and diclofenac: Removal in wastewater treatment plants and occurrence in water bodies, Chemosphere, 73, 1151-1161, 2008 .

[25] K. Choi, Y. Kim, J. Park , C. K. Park, M. Kim, Seasonal variations of several pharmaceutical residues in surface water and sewage treatment plants of Han River, Korea, Science of the Total Environment, 405 (1-3), 120-128, 2008.

[26] Z. Moldovan, Occurrences of pharmaceutical and personal care products as micropollutants in rivers from Romania, Chemosphere, 64(11), 1808-17, 2006.

[27] C. Zwieger, F. Firmmel, Oxidative treatment of pharmaceuticals in water, Water Resources, 34 (6), 1881-
1885,2000

[28] B. Subedi, K. Balakrishna, D. J. Joshua, K. Kannan, Mass loading and removal of pharmaceuticals and personal care products including psychoactives, antihypertensives, and antibiotics in two sewage treatment plants in Southern India, Chemosphere, 167, 429-437, 2017.

[29] T. Mackul'aka, M. Mosn'ya, J. `Skubákb, R. Grabicc, L. Biro`sová, Fate of psychoactive compounds in wastewater treatment plant and the possibility of their degradation using aquatic plants, Environmental Toxicology and Pharmacology, 39, 969-973, 2015.

[30] M. Papageorgiou, C. Kosma, D. Lambropoulou, Seasonal occurrence, removal, mass loading and environmental risk assessment of 55 pharmaceuticals and personal care products in a municipal wastewater treatment plant in Central Greece, Science of the Total Environment, 543, 547-569, 2016.

[31] N. H. Trana, K. Y. Gin, Occurrence and removal of pharmaceuticals, hormones, personal care products, and endocrine disrupters in a full-scale water reclamation plant, Science of The Total Environment, 599-600, 1503-1516, 2017.

[32] L.M. Gómez-Oliván, M. Galar-Martínez, H. Islas-Flores, S. García-Medina, N. SanJuan-Reyes, DNA damage and oxidative stress induced by acetylsalicylic acid in Daphnia magna, Comparative Biochemistry and Physiology, Part C, 164, 21-26, 2014.

[33] Commission of the European Communities, Technical guidance document in support of commission directive 93/67/ EEC on risk assessment for new notified substances Part II, environmental risk assessment. Luxembourg: Office for official publication of the European Communities, 1996

[34] A. Mendoza, J. Aceña, S. Pérez, M. Lópezde Alda, D. Barceló, A. Gil, Y. Valcárcel, Pharmaceuticals and iodinated contrast media in a hospital waste- water: A case study to analyse their presence and characterise their environmental risk and hazard, Environmental Research, $140,225-241,2015$.

[35] M. Grung, T. Kallqvist, S. Sakshaug, S. Skurtveit, K.V. Thomas, Environmental assessment of Norwegian priority pharmaceuticals based on the EMEA guideline, Ecotoxicology and Environmental Safety, 71:328-40, 2008.

[36] H. Sanderson, M. Thomsen, Comparative analysis of pharmaceuticals versus industrial chemicals acute aquatic toxicity classification according to the United Nations classification system for chemicals. Assessment of the (Q)SAR predictability of pharmaceuticals acute aquatic toxicity and their predominant acute toxic mode-of-action, Toxicology Letters, 187, 84-93, 2009.

[37] H. Sanderson, D. J. Johnson, C. J. Wilson, R. A. Brain, K. R. Solomon, Probabilistic hazard assessment of environmentally occurring pharmaceuticals toxicity to fish, daphnids and algae by ECOSAR screening, Toxicology Letters, 144, 383/395, 2003.

M. Gros, M. Petrović, A. Ginebreda, D. Barceló, Removal of pharmaceuticals during wastewater treatment and environmental risk assessment using hazard indexes, Environment International, 36, 15-26, 2010. 